\title{
Autolysis and intracellular enzyme release from cheese related dairy lactobacilli*
}

\author{
Wedad El-Kholy, Morsi El-Soda**, Nihal Ezzat, Hassan El Shafei
}

\begin{abstract}
Laboratory of Microbial Biochemistry, Department of Dairy Technology, Faculty of Agriculture, Alexandria University, Alexandria, Egypt
\end{abstract}

\begin{abstract}
The ability of Lactobacillus helveticus, Lb. delbrueckii subsp. bulgaricus, Lb. delbrueckii subsp. lactis, $L b$. casei, Lb. plantarum, $L b$. fermentum and $L b$, brevis to lyse under various conditions of temperature, sodium chloride concentration and $\mathrm{pH}$ was investigated. Intracellular enzymes released from the cells in vitro and in a cheese system were also considered. A temperature close to the optimun temperature for growth, a pH varying from 5.5 to 6.5 and a sodium chloride concentration varying from 0.5 to $1.0 \mathrm{M}$ as well as a freezing and thawing treatment seem to be the optimal conditions for cell autolysis. Enzymes release in vitro and in the cheese were found to be related to the rate of autolysis of the cells. (C) Inra/Elsevier, Paris
\end{abstract}

autolysis / Lactobacillus / aminopeptidase / ripening / cheese

Résumé - Autolyse et relargage des enzymes intracellulaires des lactobacilles apparentés au fromage. L'autolyse des bactéries Lactobacillus helveticus, Lb. delbrueckii subsp. bulgaricus, Lb. delbrueckii subsp. lactis, $L b$. casei, Lb. plantarum, $L b$. fermentum et $L b$. brevis a été étudiée dans des conditions différentes de température, $\mathrm{pH}$, et concentration en chlorure de sodium. Le relargage des activités enzymatiques in vitro et dans un fromage modèle a aussi été pris en considération. Les résultats obtenus montrent qu'une température proche de la température optimale de croissance de la bactérie, un $\mathrm{pH}$ variant de 5,5 à 6,5 selon les souches, ainsi qu'un traitement de congélation/décongélation sembleraient être les conditions optimales pour l'autolyse des cellules de Lactobacillus étudiées. Il a aussi été démontré que les souches montrant une forte autolyse relarguent leurs enzymes intracellulaires plus rapidement dans le caillé. (C) Inra/Elsevier, Paris

autolyse / Lactobacillus / aminopeptidase / affinage / fromage

\footnotetext{
* Oral communication at the IDF symposium 'Ripening and quality of cheese', Besançon, France, February 26-28, 1996.

** Correspondence and reprints. E-mail: morsi_elsoda@hotmail.com
} 


\section{INTRODUCTION}

Autolysis could be defined as the spontaneous desintegration of the bacterial cell, this process is of great importance during cheese ripening because it leads to the release of the intracellular enzymes that are now known to play a key role in the textural changes occurring during ripening and, for the development of the characteristic flavour of cheese.

Studies on the autolytic properties of cheese related micro-organisms have started in the early forties [16] but, it is only in the late eighties that real interest was directed towards the autolysis process and its possible impact on cheese ripening $[4,8,14]$.

Several authors determined the rate of autolysis at different temperatures $[2,15$, $21,24,31,34]$; the general conclusion indicates that the optimum temperature for autolysis varies according to the organism tested. In a limited number of studies, high rates of autolysis were measured at low temperatures [34].

As far as the influence of $\mathrm{pH}$ on the rate of autolysis was concerned, an optimum $\mathrm{pH}$ close to neutrality was observed on several occasions [26, 28], Optimum autolysis in the acidic range of $\mathrm{pH}$ were also reported [9].

Enzyme release in cheese was first reported by Law et al. [18] who described the release of intracellular dipeptidase from starter lactococci during Cheddar cheese ripening.

Twenty years later, Wilkinson et al. [35] found higher enzyme release in cheeses ripened at $10^{\circ} \mathrm{C}$ when compared to cheeses ripened at $4{ }^{\circ} \mathrm{C}$.

El Soda et al. [13] demonstrated that strains showing high autolytic properties in vitro will release their intracellular enzymes at a faster rate in a cheese system. ChapotChartier et al. [5] noticed significant differences in the rate of enzyme release in cheese made with Lactococcus lactis subsp. cremoris AM2 and L. lactis subsp. lactis NCDO763. In fact the release of enzyme from $L$. lactis subsp. cremoris AM2 was significantly higher when compared to L. lactis subsp. lactis NCDO763.

Attention was also given to the enzymes involved in the autolytic process. A detailed description of the first attempts to characterize the autolysins of lactic acid bacteria can be found in Chapot-Chartier [4]. Polyacrylamide gel electrophoresis was recently used to compare strains according to the numbers of autolysis bands. Using this method, Valence and Lortal [33] detected seven autolytic activity bands in $L b$. helveticus ISCL5. Partial purification of the enzymes was also described. A similar study was also conducted by $\emptyset$ stlie et al. [30] on Lactococcus strains where two to five lytic bands were detected. Glycosidase as well as $\mathrm{N}$-acetyl muramyl $\mathrm{L}$-alanine amidase activities were present in some of the strains.

The aim of the present contribution is to compare the autolytic properties of different Lactobacillus species and to determine the different factors affecting the process. Release of intracellular enzymes during autolysis in vitro as well as in a cheese system were also considered.

\section{MATERIALS AND METHODS}

\subsection{Cultures and growth conditions}

The micro-organisms used in this study were: Lactobacillus helveticus CNRZ 32 and 303, Lb. delbrueckii subsp. bulgaricus CNRZ 369 and 418, Lb. delbrueckii subsp. lactis CNRZ 250 and 242, Lb. plantarum CNRZ 425 and $73, L$ b. fermentum CNRZ 229 and Lb. brevis CNRZ 423. Lb. casei CNRZ 62 and $L$ b. casei UL1 were obtained from Université Laval, Quebec, Canada.

For the preparation of cells, $1000 \mathrm{~mL}$ of MRS [10] were inoculated with $3 \%$ of an active culture of the Lactobacillus strain. Cell growth phases were monitored by measuring the absorbance at $650 \mathrm{~nm}$ using an LKB Pharmacia Nova Spectrophotometer II. After 8-12 h, early stationary 
phase cells were harvested by centrifugation at $2800 \mathrm{~g}$ for $20 \mathrm{~min}$ at $4{ }^{\circ} \mathrm{C}$. The optical density and times corresponding to the early stationary phase cells are as indicated in table $I$. The pellet was then washed twice with $0.01 \mathrm{M}$ potassium phosphate buffer $\mathrm{pH}$ 7.0. The resulting bacterial pellet was resuspended in $0.2 \mathrm{M}$ potassium phosphate buffer $\mathrm{pH} 7.0$.

\subsection{Measurement of the rate of autolysis}

The cell suspension was set at an optical density of 0.8 to 1.0 . The percentage decrease in optical density at $650 \mathrm{~nm}$ after incubation for different time intervals was used as a measure of the autolytic activity. The experiments were run in triplicate.

\subsection{Influence of the physiological age of the cells on their autolytic properties}

Cells grown in MRS broth at $30^{\circ} \mathrm{C}$ for $L b$. plantarum, Lb. brevis and $\mathrm{Lb}$. casei or at $37^{\circ} \mathrm{C}$ for Lb. helveticus, Lb. delbrueckii subsp. bulgaricus, Lb. delbrueckii subsp. lactis and Lb. fermentum were harvested by centrifugation at different stages of growth: exponential growth phase, early stationary phase and stationary phase. The harvested cells were washed twice in $0.01 \mathrm{M}$ potassium phosphate buffer $\mathrm{pH}$ 7. The rate of autolysis was then determined as described previously.

\subsection{Effect of temperature on the rate of autolysis}

Experiments were carried out in potassium phosphate buffer $0.2 \mathrm{M} \mathrm{pH} 7.0$ at the following temperatures: $10,20,30,40$ and $50^{\circ} \mathrm{C}$.

\subsection{Effect of sodium chloride concentration on the rate of autolysis}

Experiments were carried out in potassium phosphate buffer $0.2 \mathrm{M} \mathrm{pH} 7.0$ at $30^{\circ} \mathrm{C}$ for $L b$. plantarum, Lb. brevis and $\mathrm{Lb}$. casei or at $37^{\circ} \mathrm{C}$ for $L b$. helveticus, Lb. delbrueckii subsp. bulgaricus, Lb. delbrueckii subsp. lactis and Lb. fermentum at the following concentrations of sodium chloride: $2,1,0.5$ and $0.1 \mathrm{M}$.

\subsection{Effect of $\mathrm{pH}$ on the rate of autolysis}

Experiments were carried in potassium phosphate buffer $0.2 \mathrm{M}$ at $30^{\circ} \mathrm{C}$ for $L b$. plantarum, Lb. brevis and Lb. casei or at $37^{\circ} \mathrm{C}$ for $\mathrm{Lb}$. helveticus, Lb. delbrueckii subsp. bulgaricus, $L b$. delbrueckii subsp. lactis and Lb. fermentum at the following $\mathrm{pH}$ values: $4.5,5.5,6.5,7.5$ and 8.5 .

Table I. The optical density and times corresponding to the early stationary phase of several lactobacilli.

Tableau I. Densités optiques et temps correspondants au début de phase stationnaire de différentes souches de lactobacilles.

\begin{tabular}{lcc}
\hline Strains & Optical density & Time (h) \\
\hline Lb. helveticus CNRZ 32 & 1.45 & 10 \\
Lb. helveticus CNRZ 303 & 1.40 & 12 \\
Lb. casei CNRZ 62 & 1.35 & 9 \\
Lb. casei CNRZ RD1 & 1.25 & 10 \\
Lb. plantarum CNRZ 425 & 1.55 & 8 \\
Lb. plantarum CNRZ 73 & 1.40 & 9 \\
Lb. delbrueckii subsp. bulgaricus CNRZ 369 & 1.50 & 9 \\
Lb. delbrueckii subsp. bulgaricus CNRZ 418 & 1.35 & 12 \\
Lb. delbrueckii subsp. lactis CNRZ 250 & 1.25 & 11 \\
Lb. delbrueckii subsp. lactis CNRZ 242 & 1.30 & 12 \\
Lb. fermentum CNRZ 229 & 1.20 & 11 \\
Lb. brevis CNRZ 423 & 1.35 & 9 \\
\hline
\end{tabular}




\subsection{Influence of lysozyme concentration on the rate of autolysis}

In order to follow the influence of lysozyme concentration on the rate of autolysis, the cells were resuspended to give a final optical density of 0.8 to 1.0 in the appropriate conditions predetermined for each strain and in the presence of 5 or $10 \mathrm{mg}$ lysozyme $\mathrm{mL}^{-1}$ of the cell suspension. The mixture was incubated at the desired temperature and the rate of autolysis measured as previously described.

\subsection{Measurement of protein and enzyme release during cell autolysis}

Aminopeptidase, dipeptidylaminopeptidase and protein release during cell autolysis were measured as follows: aliquots of the autolysing cell suspensions set at the desired conditions of buffer molarity, $\mathrm{pH}$ and sodium chloride concentration and incubated at the desired temperature were collected at different time intervals and centrifuged at $2800 \mathrm{~g}$ for $10 \mathrm{~min}$ at $4{ }^{\circ} \mathrm{C}$. The resultant supernatants containing the intracellular enzymes were stored at $-20^{\circ} \mathrm{C}$, then used to determine the protein concentration of the released cell material and to measure the aminopeptidase and dipeptidylaminopeptidase activities.

\subsection{Aminopeptidase and dipeptidylaminopeptidase activities}

The aminopeptidase activity was measured according to the procedure described by El Soda and Desmazeaud [12]. The substrate used was L-leucyl paranitroanilide (Leu- $p$ NA). The same procedure was also used to follow the dipeptidylaminopeptidase activity. The substrate used for this purpose was Arg-Pro-paranitroanilide (Arg-pro-p NA). One unit of enzymatic activity was defined as that amount of enzyme producing a variation of 0.01 unit $\cdot \mathrm{min}^{-1}$ of absorbance under the present assay conditions. The specific activity was defined as the number of activity units $\cdot \mathrm{mg}^{-1}$ of protein which is present in the supernatant.

\subsection{Protein determination}

The protein concentration was estimated according to the method of Lowry et al. [23].

\subsection{Cheese manufacture}

\subsubsection{Ras cheese curd}

Ras cheese was manufactured using laboratory scale cheese making equipments according to Abd-El-Tawab [1]. However, no starter was added to the cheese milk and lactic acid was used to secure acid development during cheese making ( $65 \mathrm{~mL} / 48 \mathrm{~L}$ milk to reach a pH of 5.76). Early stationary phase cells were collected from $1 \mathrm{~L}$ of MRS broth, the resultant pellet was washed twice in $0.01 \mathrm{M}$ phosphate buffer $\mathrm{pH} 7.0$ and then resuspended in a volume of the same buffer equivalent to $1 / 10$ of the volume of the growth media. The bacterial suspension which was frozen and thawed twice was added to $8 \mathrm{~L}$ of the milk.

In order to study the influence of lysozyme, $7 \mathrm{~g}$ of commercial lysozyme preparation (Genencor USA) per $8 \mathrm{~kg}$ of milk were added to the cell suspension prior to their addition to the milk. The cheese was ripened at $12^{\circ} \mathrm{C}$ for 45 days.

\subsubsection{Determination of aminopeptidase in the cheese extracts and in the whey}

The aminopeptidase activity present in cheese was measured in extracts of ground cheese prepared by the method described by El Abboudi et al. [11]. Cheese ( $20 \mathrm{~g})$ was mixed with $40 \mathrm{~mL}$ of phosphate buffer $(0.01 \mathrm{M} \mathrm{pH} \mathrm{7.0)}$ in a mortar. The samples were then centrifuged for $30 \mathrm{~min}$ at $5000 \mathrm{~g}$ at $4{ }^{\circ} \mathrm{C}$. After removing the upper solid fat layer, the soluble fraction was recovered and centrifuged again under the same conditions. The resulting cheese extract was used for determination of the peptidase activities.

Whey samples were collected after cutting and scalding for the determination of aminopeptidase activity.

\section{RESULTS AND DISCUSSION}

\subsection{Effect of several factors on the autolytic properties of different Lactobacillus species}

The results concerning the influence of several factors on the autolytic properties of twelve strains of lactobacilli (figure la, $b$, $c, d$ ) indicate that in most cases maximum 

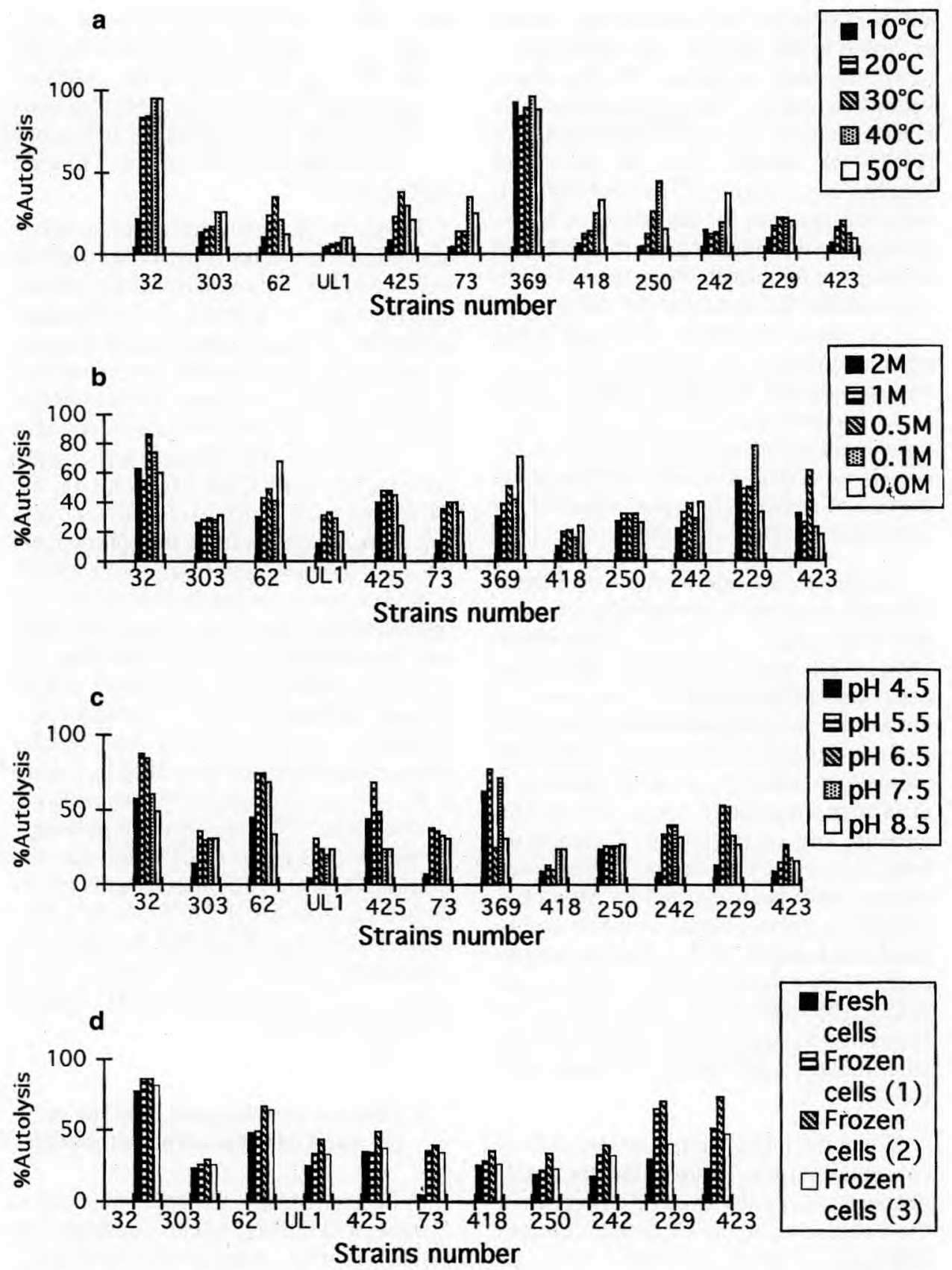

Figure 1. Effect of temperature (a), Sodium chloride concentration (b), $\mathrm{pH}(\mathbf{c})$ and freezing and thawing (d) on the autolysis of several lactobacilli after 24 hours.

Figure 1. Influence de la température (a), de la teneur en chlorure de sodium (b), du pH (c) et des cycles de congélation, décongélation (d) sur l'autolyse de plusieurs souches de lactobacilles après 24 heures d'incubation. 
autolysis occurred at a temperature similar or closed to the optimum growth temperature of the micro-organisms. Similar observations were also made by Lortal et al. [21] in the case of $L b$, helveticus CNRZ 414. Our results however differ from the findings of Neujahr and Logardt [25] where the optimum temperature for the autolysis of $L b$. fermentum was higher than the optimum temperature for growth. From figure $1 a$, it is also possible to notice that the rate of autolysis is strain dependent. Although maximum autolysis for $L b$. helveticus was $40^{\circ} \mathrm{C}$, $95 \%$ of strain $L b$. helveticus CNRZ 32 lysed at this temperature while only $26 \%$ autolysis could be measured in the case of $L b$. helveticus CNRZ 303; other differences in the rate of autolysis between strains of the same species can also be seen.

In general, the rate of autolysis increased with increases in incubation temperature in the range of $10-40^{\circ} \mathrm{C}$. All the strains showed little autolysis at $10^{\circ} \mathrm{C}$, while their behaviour differed at $50^{\circ} \mathrm{C}$. Our results in this respect are comparable to the findings of Bie and Sjöstrom [2], who measured an increase in autolysis with the increase in incubation temperature. They also could not measure any autolysis at $6{ }^{\circ} \mathrm{C}$ during the first 5 days of the experiment. Similar observations were also reported by Mou et al. [24] for L. lactis subsp. cremoris and by Sund and Linder [32] for viridans streptococci. Higher autolysis at $40{ }^{\circ} \mathrm{C}$ were also detected by Lemee et al. [19] for Propionibacterium freudenreichii CNRZ 725. The latter authors also noticed very little autolysis at $10^{\circ} \mathrm{C}$.

When the influence of sodium chloride concentration was investigated, the results obtained (figure $1 b$ ) revealed differences in the behaviour of the different cultures. Although $\mathrm{Lb}$. helveticus CNRZ 32, Lb. casei UL1, Lb. plantarum CNRZ 425, Lb. fermentum CNRZ 229 and $L$ b. brevis CNRZ 423 showed higher levels of autolysis in the presence of sodium chloride, the rest of the strains were either not influenced by the pre- sence of salt or autolysed at lower rates when sodium chloride was added to the cell suspension. In their work on the autolysis of lactococci, Vegarud et al. [34] also noticed differences in the autolytic behaviour of their cultures towards sodium chloride concentration.

Figure Ic illustrates the rate of autolysis of the different strains at $\mathrm{pH}$ values varying from 4.5 to 8.5 . The results obtained indicate that the rate of autolysis is significantly influenced by the $\mathrm{pH}$ value. It is for instance possible to notice that for $L b$. helveticus CNRZ 32, the rate of autolysis measured at $\mathrm{pH} 4.5$ was $57 \%$ while the value reported at pH 5.5 was $87 \%$. The obtained rate of autolysis for $L b$. casei CNRZ 62 were 45,74 , 74,68 and $34 \%$ at $\mathrm{pH} 4.5,5.5,6.5,7.5$ and 8.5 , respectively. As far as the optimum $\mathrm{pH}$ for autolysis was concerned, most strains exhibited maximum autolysis at $\mathrm{pH}$ 5.5. An optimum $\mathrm{pH}$ for autolysis in the acidic range was also reported by Coyette and Ghuysen [7] for Lactobacillus acidophilus and by Ohmiya and Sato [29] for Lactobacillus acidophilus, L. helveticus and $L$. casei. Similar observations were also described by Lemee et al. [19] for Propionibacterium freudenreichii CNRZ 725. Lactobacillus delbrueckii subsp. bulgaricus CNRZ 369 was distinguished from the other strains by its higher autolysis at $\mathrm{pH} 7.5$ (figure 1c). Lactobacillus delbrueckii subsp. bulgaricus is comparable in that respect to the $L$. lactis subsp. cremoris strains HP and ML studied by Mou et al. [24].

\subsection{Effect of freezing and thawing on the autolysis of several lactobacilli}

As a general rule, the cells subjected to freezing and thawing cycles autolysed at a faster rate when compared to fresh cells. The differences in the rate of autolysis between fresh cells and cells subjected to freezing and thawing differed according to the strain tested (figure $1 d$ ). In the case of $L b$. fermentum CNRZ 229, $30 \%$ autolysis could 
be measured with fresh cells after $48 \mathrm{~h}$ of incubation, while the value was $71 \%$ when the cells were subjected to two cycles of freezing and thawing. The corresponding values in the case of $L b$. casei CNRZ 62 were $48 \%$ and $67 \%$ respectively. Our findings in that respect are comparable to the work of Ohmiya and Sato [29] who demonstrated that the rate of autolysis of $\mathrm{Lb}$. helveticus stored at $-20^{\circ} \mathrm{C}$ overnight and then thawed was $45 \%$ higher when compared to cells stored at $3{ }^{\circ} \mathrm{C}$ for the same period of time. Freezing and thawing cycles had little effect on the rate of autolysis of $\mathrm{Lb}$, helveticus CNRZ 32 and 303.

When the number of freezing and thawing cycles were compared, it clearly appeared that cells subjected to two cycles of freezing and thawing autolysed faster than cells subjected to one or three cycles of freezing and thawing. The decrease in the rate of autolysis after the third cycle may be due to a partial inhibition of the autolysis due to the physical treatment.

\subsection{Influence of the physiological age of the cells on the rate of autolysis for different strains of lactobacilli}

The effect of harvesting $L b$. helveticus CNRZ 32, Lb. casei CNRZ 62, Lb. plantarum CNRZ 425 and $L$ b. delbrueckii subsp. bulgaricus CNRZ 369 at different stages of growth on the rate of autolysis is shown in figure 2 . The results obtained indicate an increase in autolysis during exponential growth reaching maximum activity before transition to the stationary phase, this was then followed by a marked decrease in the autolytic activity. For instance, $80 \%$ autolysis could be measured in the case of the cells of $L b$. helveticus CNRZ 32 harvested during exponential growth, while only $16 \%$ autolysis was detected in the cells harvested during late stationary phase. Similar trends were also observed for $L$ b. casei CNRZ 62, Lb. plantarum CNRZ 425 and Lb. delbrueckii subsp. bulgaricus CNRZ 369. Our results on the effect of the physiological age of the cells on the rate of autolysis are comparable to the results of Neujahr and Logardt [25] Lortal et al. [22] and Ohmiya and Sato [29] on lactobacilli and Mou et al. [24] and Niskasaari [26] on L. lactis subsp. cremoris. Similar observations were also described by Lemee et al. [19] for Propionibacterium freudenreichii CNRZ 725. In contrast, strains of viridans streptococci showed the identical autolysis in both exponential and stationary phases of growth [32]. It should, however, be noticed that autolysin activity was detected in both log and stationary cells of Lb. acidophilus [7] but, the action of the enzyme on stationary phase cells was inhibited.

\subsection{Autolytic properties of several lac- tobacilli under optimum conditions and cheese ripening conditions}

The combined action of $\mathrm{pH}$, temperature, $\mathrm{NaCl}$ concentration and freezing and thawing were studied in the presence and absence of lysozyme at the optimal conditions for cell lysis. A similar study was also undertaken at conditions close to cheese ripening, which were a $\mathrm{pH}$ of $5.5,0.5 \mathrm{M} \mathrm{NaCl}$ and an incubation temperature of $10^{\circ} \mathrm{C}$.

Figure $3 a$ illustrates the rate of autolysis of the four Lactobacillus species under optimum conditions for cell autolysis and indicates a gradual increase in the rate of autolysis of the different strains as a function of time, which was highest in the case of $L b$. plantarum CNRZ 425 , followed by $L b$. helveticus CNRZ 32, Lb. casei CNRZ 62 and $L$ b. delbrueckii subsp. bulgaricus $\mathrm{CNRZ}$ 369. In their comparative study on the autolytic properties of the lactobacilli, Ohmiya and Sato [29] also noticed higher rates of autolysis in $\mathrm{Lb}$. helveticus when compared to Lb. casei.

In the presence of lysozyme, higher rates of autolysis could be measured after $1 \mathrm{~h}$ of incubation. The values were $89 \%$ and $68 \%$ 
a

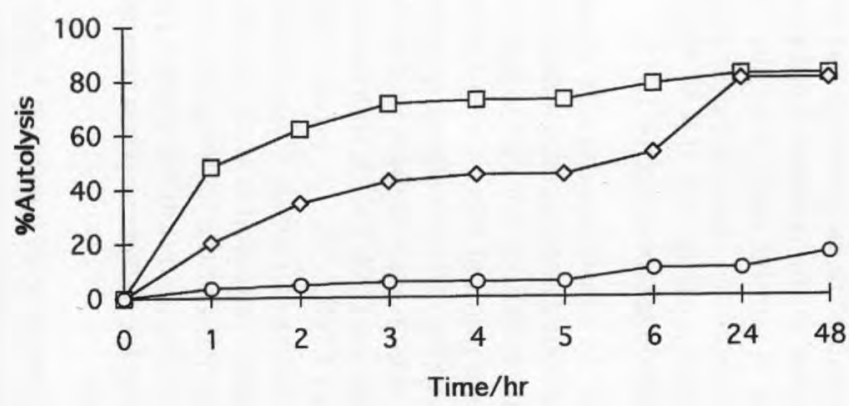

C

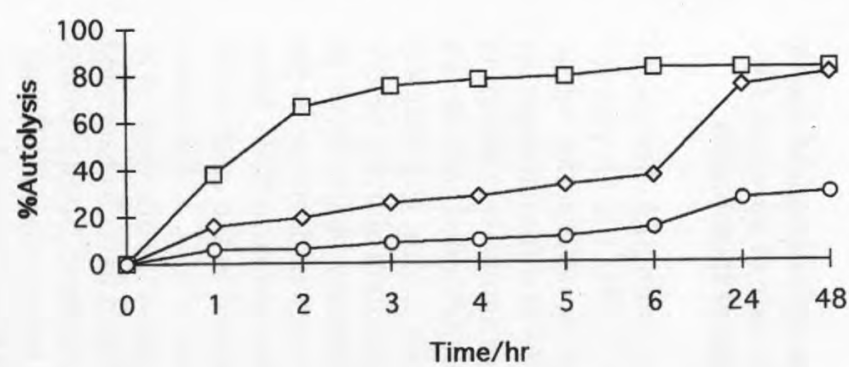

b

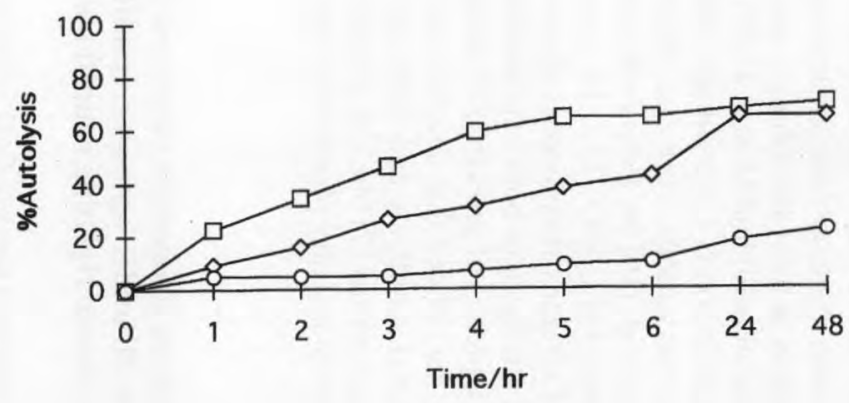

d

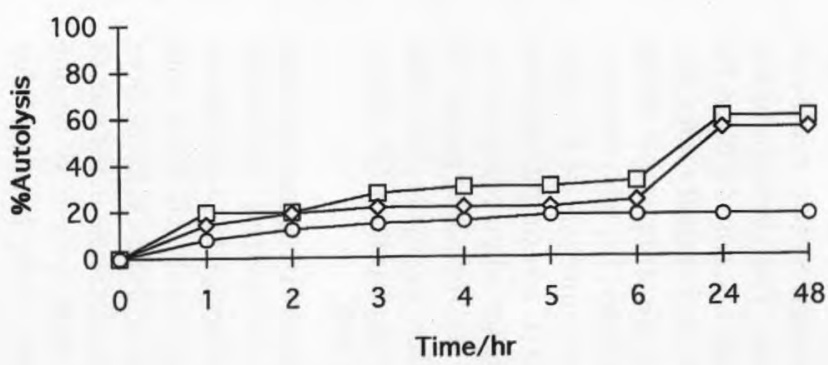

Figure 2. Influence of the physiological age of the cells on the rate of autolysis for different strains of lactobacilli: Lb. helveticus CNRZ 32 (a), Lb. casei CNRZ 62 (b), Lb. plantarum CNRZ 425 (c) and Lb. bulgaricus CNRZ 369 (d). Cells were incubated at $35^{\circ} \mathrm{C}$ in $0.2 \mathrm{M}$ phosphate buffer pH 5.5 containing $0.5 \mathrm{M}$ sodium chloride (frozen cells 1 cycle ). $\square$ Exponential phase cells; $\diamond$ early stationay phase cells; $\bigcirc$ late stationary phase cells.

Figure 2. Influence de l'âge physiologique des cellules sur la vitesse d'autolyse des différentes souches de lactobacilles : Lb. helveticus CNRZ 32 (a), Lb. casei CNRZ 62 (b), Lb. plantarum CNRZ 425 (c) et $L$ b. bulgaricus CNRZ 369 (d). Cellules incubées à $35^{\circ} \mathrm{C}$ en tampon de phosphate $0,2 \mathrm{M}$ et pH 5,5 contenant $0,5 \mathrm{M}$ de chlorure de sodium (un cycle de congélation/décongélation). $\square$ Phase exponentielle ; $\diamond$ début de la phase stationnaire ; $\bigcirc$ fin de la phase stationnaire. 
for $L$ b. delbrueckii subsp. bulgaricus $\mathrm{CNRZ}$ 369 and Lb. helveticus CNRZ 32, respectively. The autolysis then reached a plateau, maintained during the rest of the incubation time. The same trend, but to a lower extent, could also be observed for $L b$. plantarum CNRZ 425 and Lb. casei CNRZ 62 (figure $3 b)$.

When the cell suspensions were incubated under cheese ripening conditions very little or no autolysis could be measured during the first $6 \mathrm{~h}$ of incubation. This was then followed by a gradual increase in the \% autolysis, which reached $79 \%$ for $\mathrm{Lb}$. helveticus CNRZ 32, $54 \%$ for $L$ b. casei CNRZ $62,34 \%$ for $L$ b. plantarum CNRZ 425 and
$17 \%$ for $L b$. delbrueckii subsp. bulgaricus CNRZ 369 after $120 \mathrm{~h}$ (figure $4 a$ ). As a general rule, the two strains following the thermobacterium group were more sensitive to lysozyme when compared to $L b$. casei CNRZ 62 and $L b$. plantarum CNRZ 425 . When lysozyme was added to the cell suspension (figure $4 b$ ), autolysis could be measured from the first hour of incubation in both $\mathrm{Lb}$. helveticus CNRZ 32 and $\mathrm{Lb}$. delbrueckii subsp. bulgaricus CNRZ 369 and increased gradually during the $120 \mathrm{~h}$ of incubation used for the experiment. For the two other strains, the lag phase observed in the absence of lysozyme was also noticed in the presence of the lytic enzyme. Positive effect
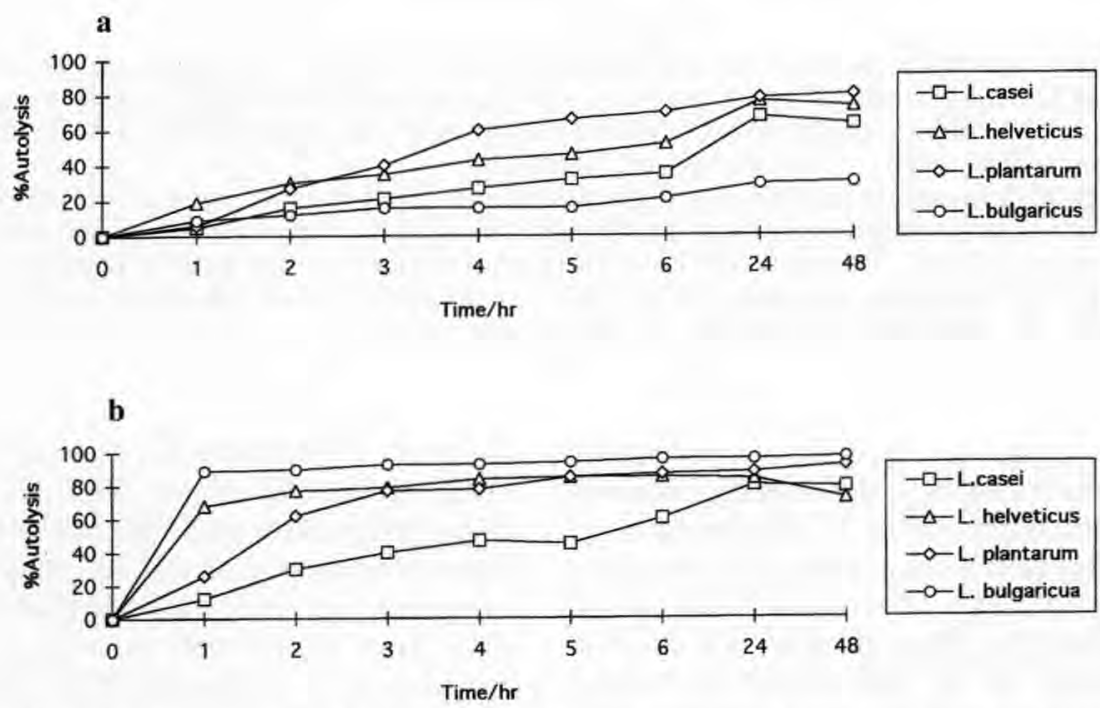

Figure 3. Autolytic properties of several lactobacilli (optimum conditions for autolysis). Frozen and thawed cells ( 2 cycles) were incubated at $30^{\circ} \mathrm{C}$ ( L. casei 62 and L. plantarum 425 ) or $40^{\circ} \mathrm{C}(\mathrm{L}$. helveticus 32 and $L$. delbrueckii subsp. bulgaricus 369 ) in $0.2 \mathrm{M}$ phosphate buffer $\mathrm{pH} 5.5$ ( $L$, helveticus 32 , L. delbrueckii subsp bulgaricus 369 and L. plantarum 425 ) or $\mathrm{pH} 6.5$ (L. casei 62 ) containing $0.5 \mathrm{M}$ sodium chloride ( $L$. helveticus 32 and $L$. delbrueckii subsp bulgaricus 369 and $L$. casei 62 ) or $1 \mathrm{M}$ sodium chloride ( $L$. plantarum 425 ). a. In the absence of lysozyme. b. In the presence of $5 \mathrm{mg} / \mathrm{mL}$ lysozyme.

Figure 3. Propriétés autolytiques de différentes souches de lactobacilles (conditions optimales de l'autolyse). Les cellules ont été congelées et décongelées ( 2 cycles) et incubées à $30^{\circ} \mathrm{C}$ ( L. casei 62 et L. plantarum 425 ) ou $40^{\circ} \mathrm{C}$ ( $L$. helveticus 32 et $L$. delbrueckii subsp. bulgaricus 369 ) en tampon de phosphate $0,2 \mathrm{M}$ et pH 5,5 (L. helveticus 32, L. delbrueckii subsp. bulgaricus 369 et $L$. plantarum 425 ) ou pH 6,5 (L. casei 62) 0,5 M de chlorure de sodium ( $L$. helveticus 32 et $L$. delbrueckii subsp. bulgaricus 369 et $L$. casei 62 ) ou $1 \mathrm{M}$ de chlorure de sodium ( $L$. plantarum 425 ). a. En l'absence de lysozyme. b. En présence de $5 \mathrm{mg} / \mathrm{mL}$ de lysozyme. 

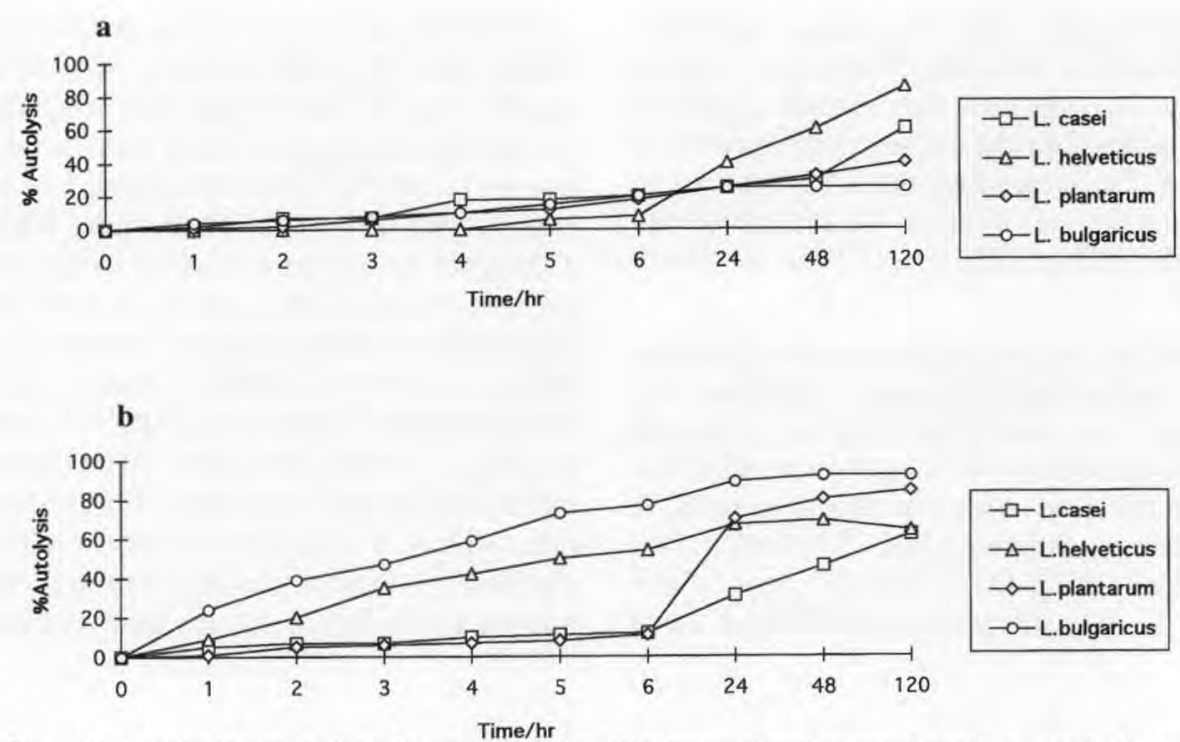

Figure 4. Autolytic properties of several lactobacilli (cheese ripening conditions): L. casei $62, L$. helveticus $32, L$. plantarum 425 and $L$. bulgaricus 369 . Frozen and thawed cells ( 2 cycles) were incubated at $10^{\circ} \mathrm{C}$ in $0.2 \mathrm{M}$ phosphate buffer $\mathrm{pH} 5.5$ containing $0.5 \mathrm{M}$ sodium chloride. a. In the absence of lysozyme. b. In the presence of $5 \mathrm{mg} / \mathrm{mL}$ lysozyme.

Figure 4. Influence de l'âge physiologique des cellules sur la vitesse d'autolyse des différentes souches de lactobacilles (conditions de l'affinage des fromages) : L. casei 62, L helveticus 32 , $L$ plantarum 425 et $L$. bulgaricus 369 . Les cellules ont été congelées et décongelées ( 2 cycles) et incubées à $10{ }^{\circ} \mathrm{C}$ en tampon phosphate $0,2 \mathrm{M}$ et pH 5,5 contenant $0,5 \mathrm{M}$ de chlorure de sodium. a. En l'absence de lysozyme. b. En présence de $5 \mathrm{mg} / \mathrm{mL}$ de lysozyme.

of lysozyme on cell lysis was previously demonstrated in L. lactis subsp. cremoris by Niskasaari et al. [27]. The resistance of lactobacilli to lysozyme was also previously described in Lb. fermentum by Logart and Neujahr [20]. The resistance of a strain to lysis may be due to the absence of an autolytic system or effective regulation of the autolytic enzymes by membrane-associated lipoteichoic acid and related compounds [6].

\subsection{Aminopeptidase and dipeptidyl- aminopeptidase release during the autolysis of several lactobacilli under optimum conditions and cheese ripening conditions}

The results reveal the presence of active aminopeptidase and dipeptidylaminopeptidase activity in $L b$. helveticus CNRZ 32,
Lb. casei CNRZ 62 and Lb. plantarum CNRZ 425. Lb. helveticus CNRZ 32 is distinguished from the two other strains by its higher aminopeptidase and dipeptidylaminopeptidase activities; it showed $68.4 \%$ and $43.6 \%$ higher aminopeptidase activity when compared to Lb. plantarum CNRZ 425 and Lb. casei CNRZ 62, respectively. The corresponding values for dipeptidylaminopeptidase were $40.7 \%$ and $37.5 \%$, respectively. Lb. plantarum CNRZ 425 was also slightly more active than $L b$. casei CNRZ 62 .

The release of the intracellular aminopeptidase and dipeptidylaminopeptidase enzymes from the bacterial cells was then studied in $\mathrm{Lb}$. helveticus CNRZ 32, $\mathrm{Lb}$. casei CNRZ 62 and $L b$. plantarum CNRZ 425 under the optimum conditions for cell auto- 

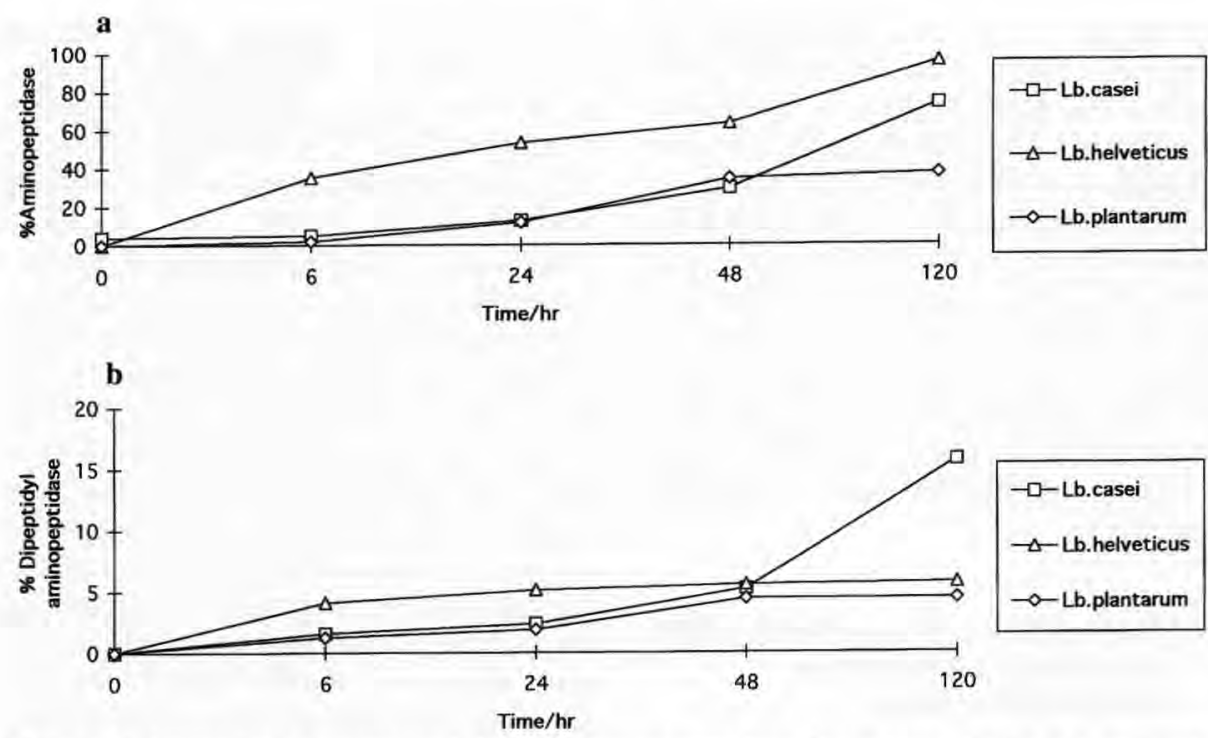

Figure 5. Aminopeptidase (a), and dipeptidylaminopeptidase (b), release during the autolysis of $L$. casei 62, L. helveticus $32, L$. plantarum 425 and $L$. bulgaricus 369 under cheese ripening conditions: results are expressed as percent of the total extract obtained after grinding the cells. Figure 5. Relargage de l'activité aminopeptidase (a) et dipeptidylaminopeptidase (b) pendant l'autolyse de $L$. casei $62, L$. helveticus $32, L$. plantarum 425 et $L$. bulgaricus 369 incubées dans les conditions de l'affinage des fromages. Les résultats sont exprimés comme un pourcentage de l'extrait total obtenu après le broyages de cellules.

lysis as well as under cheese ripening conditions $(\mathrm{pH} 5.5,0.5 \mathrm{M}$ sodium chloride and a temperature of $\left.10^{\circ} \mathrm{C}\right)$. The results illustrated in figure $5 a$ indicate a gradual release of the aminopeptidase and dipeptidylaminopeptidase activities from the cells as a function of time. In the case of $L b$. helveticus CNRZ 32, the released intracellular peptidase was detected from the first hour of incubation under both the optimum conditions for enzyme release and the cheese ripening conditions. On the other hand, a lag time vaying from 2 to $6 \mathrm{~h}$ was necessary before the detection of such enzymes in the case of $L b$. plantarum CNRZ 425 or $L b$. casei CNRZ 62. In the three strains tested, the rate of enzyme release was lower when measured in cells incubated under ripening conditions. It was, for instance, possible to measure $53 \%$ aminopeptidase release from Lb. helveticus CNRZ 32 after $24 \mathrm{~h}$ when the cells were incubated at $10^{\circ} \mathrm{C}$; the corresponding value for cells incubated at $40^{\circ} \mathrm{C}$ was $76 \%$. In the case of $\mathrm{Lb}$. casei CNRZ 62 , the enzyme released after $24 \mathrm{~h}$ was 13 and $84 \%$ for cells incubated at 10 and $30^{\circ} \mathrm{C}$, respectively. A similar trend is also noticed for $L$ b. plantarum CNRZ 425 .

Figure $5 b$ also shows that the rate of aminopeptidase release is much higher when compared to the rate of dipeptidylaminopeptidase release in the three species tested. In fact in $\mathbf{L b}$. helveticus CNRZ 32, aminopeptidase release was $76 \%$ after $24 \mathrm{~h}$ of incubation at $40^{\circ} \mathrm{C}$, the corresponding value for the dipeptidylaminopeptidase was only $5 \%$. In the case of $L b$. plantarum CNRZ 425 and $L b$. casei CNRZ 62, aminopeptidase release from cells incubated at $30^{\circ} \mathrm{C}$ was 36 and $84 \%$, respectively, for the aminopeptidase, while it was 6 and $10 \%$, res- 
pectively, for dipeptidylaminopeptidase. As a general rule, $L b$, helveticus CNRZ 32 is distinguished from the other two strains by its higher rate of enzyme release. For cells incubated at $10{ }^{\circ} \mathrm{C}$ for $120 \mathrm{~h}, \mathrm{Lb}$. helveticus CNRZ 32 exhibited $96 \%$ aminopeptidase release. The values obtained for $L b$. casei CNRZ 62 and $L b$. plantarum CNRZ 425 were 74 and $29 \%$, respectively. The percentage release of dipeptidylaminopeptidase under the same conditions for $\mathrm{Lb}$. helveticus CNRZ 32, Lb. casei CNRZ 62 and Lb. plantarum CNRZ 425 were 6,16 and $4 \%$ respectively.

\subsection{Characteristics of Ras cheese made with autolysing cells from Lactobacillus species}

The chemical composition of control cheese and cheese with added frozen cells of $L b$. helveticus CNRZ 32, Lb. helveticus CNRZ 32 + lysozyme, $L$ b. casei CNRZ 62, $L b$, plantarum CNRZ 425 and $L b$. delbrueckii subsp. bulgaricus CNRZ 369 indicated that the different treatments did not affect the composition of Ras cheese through the ripening period (results not shown). The gross composition of the cheese made with $L b$. helveticus CNRZ 32, Lb. helveticus CNRZ 32 + lysozyme, $L$ b. casei CNRZ 62 , $L$ b. plantarum CNRZ 425 and $L b$. delbrueckii subsp bulgaricus CNZR 369 treated cheese was rather close to that of control. The mean values for $\mathrm{pH}$, dry matter $\%$, fat $\%$ and protein $\%$ in the 6 weeks old cheese were $5.1,69 \%, 35.37 \%$, and $29.56 \%$ respectively.

\subsection{Release of peptidase during cheese ripening}

The aminopeptidase activity of the different micro-organisms was selected as a marker enzyme for cell lysis. In the case of Lb. helveticus CNRZ 32, the aminopeptidase was detected early in the cheese extract. As a matter of fact, 49 aminopeptidase acti- vity units per $100 \mathrm{~g}$ dry weight of cheese could be detected from the first day of manufacture. The mean value for the other strains were about $0.18 / 100 \mathrm{~g}$ dry weight of cheese. The corresponding values after one week were 23,22 and $21 / 100 \mathrm{~g}$ dry weight of cheese for $L b$. casei CNRZ 62, Lb. plantarum CNRZ 425 and $L b$. delbrueckii subsp. .bulgaricus CNZR 369, respectively, while the value was $59 / 100 \mathrm{~g}$ dry weight of cheese for $L b$. helveticus CNRZ 32. After 2 weeks of ripening, maximum release of the $L b$. helveticus $\mathrm{CNRZ} 32$ aminopeptidase was reached. Aminopeptidase activity in the cheese was then stable till the end of the ripening time (figure 6 ). A similar trend was also noticed in the other strains but, maximum release was reached after 3 weeks in Lb. delbrueckii subsp. bulgaricus CNRZ 369 , and 4 weeks in Lb. casei CNRZ 62 and Lb. plantarum CNRZ 425.

In the cheese made with $L b$. helveticus CNRZ 32 cells treated with lysozyme, the values of the released aminopeptidase were very low and only slightly higher than those of control, while $85 \%$ of the activity was detected in the whey (results not shown) which indicates a rapid release of the enzyme during the early stages of cheesemaking. This finding may explain the lower levels of aminopeptidase in the cheese made with lysozyme treated $L b$. helveticus CNRZ 32 .

The release of intracellular peptidase by autolysis from the cells was previously shown by several authors [17, 18]. Birkeland et al. [3] detected lactate dehydrogenase $(\mathrm{LDH})$ and proline iminopeptidase (PIP) activity in the cheese matrix during the early stages of the ripening period.

El-Soda et al. [13] monitored the release of aminopeptidase activity from a highly autolytic and a poorly autolytic strain of $L b$. case $i$ in Cheddar cheese. The enzyme could be detected in the cheese manufactured with the highly autolytic strain after $48 \mathrm{~h}$ of ripening, while a week was necessary to detect the activity in the cheese made with the strain showing little autolysis. 


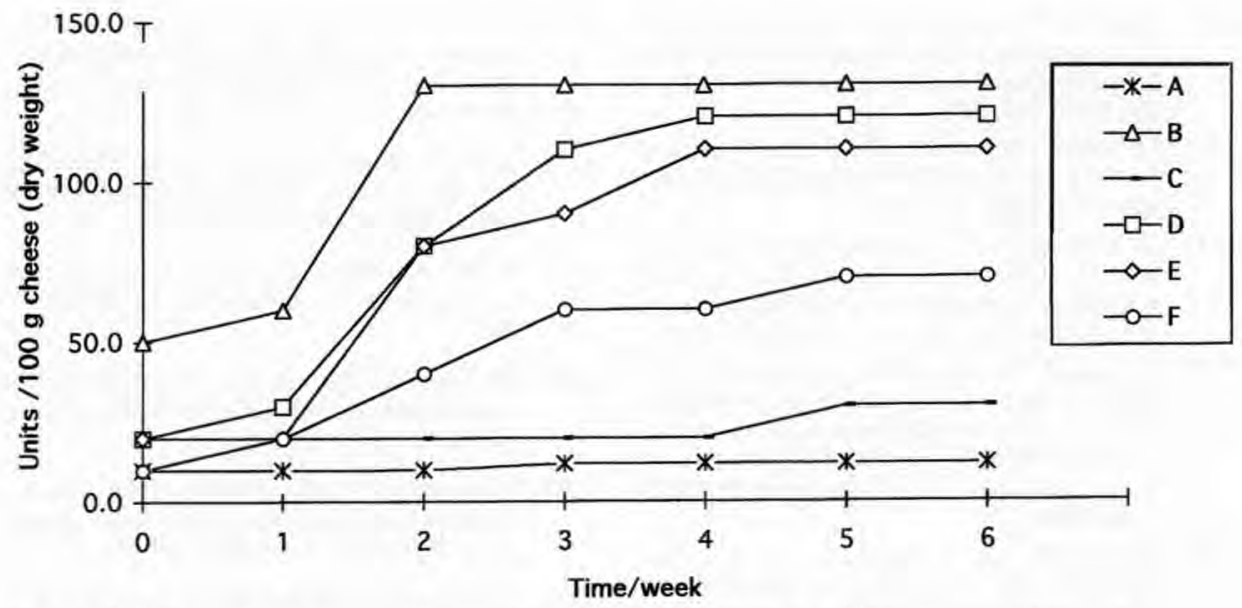

Figure 6. Release of aminopeptidase activity from several lactobacilli incorporated in a cheese system. A. Control. B. Lb. helveticus CNRZ 32. C. Lb. helveticus CNRZ $32+5 \mathrm{mg} / \mathrm{mL}$ lysozyme. D. Lb. casei CNRZ 62. E. Lb. plantarum CNRZ 425. F. Lb. bulgaricus CNRZ 369.

Figure 6. Relargage de l'activité aminopeptidase à partir de cellules de lactobacilles incorporées dans un caillé modèle. A. Témoin. B. Lb. helveticus CNRZ 32, C. Lb. helveticus CNRZ $32+5 \mathrm{mg} / \mathrm{mL}$ lysozyme. D. Lb. casei CNRZ 62. E. Lb. plantarum CNRZ 425. F. Lb. bulgaricus CNRZ 369.

More recently, Wilkinson et al. [35] noticed that the increase of salt in moisture levels in cheese in the range $0.4-5 \%$ was accompanied by an increase in the activity of lactate dehydrogenase (LDH), glucose-6phosphate dehydrogenase (G6PDH) and a decrease in post-proline dipeptidyl aminopeptidase (PPDA). Holding the crude cell free extract containing marker intracellular enzymes in a cheese like environment indicated that LDH was significantly more stable than G6PDH or PPDA.

Chapot-Chartier et al. [5] showed that decrease of cell viability was accompanied by the observation of disrupted cells by electron microscopy and the release of intracellular peptidase in the cheese.

\section{CONCLUSION}

This work indicates the importance of selecting adjuncts' cells according to their autolytic properties and it also emphasizes the necessity to understand the conditions leading to cell autolysis.

\section{REFERENCES}

[1] Abd-El-Tawab G., The manufacture of Ras cheese, in: Youssef E.H., Studies on Ras cheese, M. Sc. Thesis, Ain-Shams University, 1963.

[2] Bie R., Sjöstrom G., Autolytic properties of some lactic acid bacteria used in cheese production. Part II- Experiments with fluid substrates and cheese, Milchwissenschaft 30 (1975) 739-747.

[3] Birkeland S., Abrahamsen R., Langsrud T., Accelerated cheese ripening: use of $\mathrm{lac}^{-}$mutants of lactococci, J. Dairy Res. 59 (1992) 389-400.

[4] Chapot-Chartier M.P., Les autolysines des bactéries lactiques, Le Lait 76 (1996) 91-109.

[5] Chapot-Chartier M.P., Deniel C., Rousseau M., Vassal L., Gripon J.C., Autolysis of two strains of Lactococcus lactis during cheese ripening, Int. Dairy J. 4 (1994) 251-269.

[6] Cleveland R., Holtje J., Wicken A., Tomasz A., Daneo-Moore L., Shockman G., Inhibition of bacterial wall lysins by lipoteichoic acids and related compounds, Biochem. Biophys. Res. Commun. 67 (1975) 1128-1135.

[7] Coyette J., Ghuysen J.M., Wall autolysis of Lactobacillus acidohpilus strain 63 AM, Biochemistry 9 (1970) 2952-2955.

[8] Crow V.L., Coolbear T., Gopal P.K., Martley F.G., Mckay L.L., Riepe H., The role of autolysis of Lactic acid bacteria in the ripening of cheese, Int. Dairy J. 5 (1995) 855-875. 
[9] Dako E., El Soda M., Vuillemard J.C., Simard R.E., Autolytic properties and aminopeptidase activities of lactic acid bacteria, Food Res. Intern. 28 (1995) 503-509.

[10] De Man J., Rogosa M., Sharpe E, A medium for the cultivation of lactobacilli, J. Appl. Bacteriol. 23 (1960) 130-135.

[11] El Abboudi M., El-Soda M., Pandian S., Barreau M., Trepanier G., Simard R., Peptidase activities in debittering and nondebittering strains of lactobacilli, Int. Dairy J. I (1991) 55-64.

[12] El Soda M., Desmazeaud M., Les peptide-hydrolases des Lactobacillus du groupe thermobacterium: 1. Mise en evidence de ces actívites chez Lactobacillus helveticus, L acidophilus, L. lactis et $L$ bulgaricus, Can. J. Microbiol. 28 (1982) 1181-1188.

[13] El Soda M., Lim L., Olson N., Autolytic properties of several Lactobacillus casei strains, J. Dairy Sci. 76 (suppl.) (1993), 130 (abstract)

[14] El Soda M., Farkye N., Vuillemard J., Simard R., Olson N., El Kholy W., Dako E., Medrano E., Gaber M., Lim L., Autolysis of lactic acid bacteria: Impact on flavour development in cheese, in: Charalambous G. (Ed.), Food flavors: Generation analysis and process influence, Elsevier Science B.V., Amsterdam, 1995, pp. 2205-2223.

[15] Femández Murga M.L., Pesce de Ruiz Holgado A., De Valdez G.F., Influence of the incubation temperature on the autolytic activity of Lactobacillus acidophilus, J. Appl. Bacteriol. 78 (1995) 426-429.

[16] Hansen A., A study in cheese ripening. The influence of autolyzed cells of Streptococcus cremoris and Streptocccus lactis on the development of Lactobacillus casei, J. Dairy Sci. 24 (1941) 969-975

[17] Law B., The accelerated ripening of cheese, In: Davies F.L., Law B.A. (Eds.), Advances in the microbiology and biochemistry of cheese and fermented milk, Elsevier Applied Science Publishers, London, 1984, pp. 209-228.

[18] Law B., Sharpe M., Reiter B., The release of intracellular dipeptidase from starter streptococci during Cheddar cheese ripening, J. Dairy Res. 41 (1974) 137-146.

[19] Lemee R., Lortal S., Cesselin B.. Heijenoort J., Involvement of an $\mathrm{N}$-acetylglucosaminidase in autolysis of Propionibacterium freudenreichii CNRZ 725, Appl. Environ. Microbiol. 60 (1994) 4351-4358.

[20] Logart I., Neujahr H., Lysis of modified cell walls of Lactobacillus fermentum, J. Bacteriol. 124 (1975) 73-77.

[21] Lortal S., Boyaval P., Van Heijenoort J., Influence de plusieurs facteurs sur l'autolyse de Lactobacillus helveticus CNRZ 414, Lait 69 (1989) 223-231.
[22] Lortal S., Rousseau M., Boyaval P., Van Heijenoort J., Cell wall and autolytic system of Lactobacillus helveticus ATCC 12046, J. Gen. Microbiol. 137 (1991) 549-559.

[23] Lowry O., Resebrough A., Forr L., Randall R., Protein measurments with the Folin phenol reagent, J. Biol. Chem. 193 (1951) 265-275.

[24] Mou L., Sullivan J., Jago G., Autolysis of Streptococcus cremoris, J. Dairy Res. 43 (1976) 275 282.

[25] Neujahr H.Y., Logardt I.M., Autolytic enzyme system from Lactobacillus fermenti, Biochemistry 12 (1973) 2578-2583.

[26] Niskasaari K., Characteristics of the autolysis of variants of Lactococcus lactis subsp. cremoris, J. Dairy Res. 56 (1989) 639-649.

[27] Niskasaari K., Rimpilainen A., Lassila L., Forsen I., Enzymatic lysis of Streptococcus lactis subsp. cremoris; a method for plasma membrane preparation of the slime-forming strain MLS96, Microbios 54 (1988) 113-126.

[28] Ohmiya K., Sato Y., Studies on the proteolytic action of dairy lactic acid bacteria. IX. Autolysis and proteolytic action of Streptococcus cremoris and Lactobacillus helveticus, Agr. Biol. Chem. 33 (1969) 1628-1635.

[29] Ohmiya K., Sato Y., Promotion of autolysis in lactobacilli, Agr. Biol. Chem. 39 (1975) 585589.

[30] Østlie H.M., Vegarud G., Langsrud T., Autolysis of Lactococci: Detection of lytic enzymes by polyacrylamide gel electrophoresis and characterization in buffer systems, Appl. Environ. Microbiol. 61 (1996) 3598-3603.

[31] Sandholm E., Sarimo S., Autolysis of Streptococcus thermophilus, FEMS Microbiol. Lett. 11 (1981) 125-129.

[32] Sund M.L., Linder L., Autolysis in strains of viridans streptococci, J. Gen. Microbiol. 96 (1976) 87-94 .

[33] Valence F., Lortal S., Zymogram and preliminary characterization of Lactobacillus helveticus autolysins, Appl. Environ. Microbiol. 61 (1995) 3391-3399.

[34] Vegarud G., Castberg H,, Langsrud T, Autolysis of group N streptococci. Effect of media composition modification and temperature, $\mathbf{J}$. Dairy Sci. 66 (1983) 2294-2302.

[35] Wilkinson M.G., Guinee T.P., Fox P.F., Factors which may influence the determination of autolysis of starter bacteria during Cheddar cheese ripening. Int. Dairy J. 4 (1994) 141-160. 